\title{
THE ROLES OF PUBLIC RELATIONS (PR) PRACTICES AS PROFESSIONAL PROFESSION IN MALAYSIA
}

\author{
Aida Zuliyana Ahmad Anuar (a)*, Nan Zakiah Megat Ibrahim (b), Aida Suhana Abd Hamid (c) \\ *Corresponding author \\ (a) (Faculty of Business, Accountancy and Social Sciences, KUPTMKL, Malaysia, aidazuliyana36@gmail.com \\ (b) Faculty of Business, Accountancy and Social Sciences, KUPTMKL, Malaysia, zakiah@kuptm.edu.my \\ (c) Faculty of Business, Accountancy and Social Sciences, KUPTMKL, Malaysia, aidasuhanahamid@gmail.com
}

\begin{abstract}
Public relations (PR) function to enhance a good reputation and image of the organization. Currently, PR roles become more extensively to increase brand awareness and act as intermediate communication between the organization and the public. The functions of PR practitioner become tougher caused the advancement of technology, creation of a new market that controlled by current prime change, political changes and legal regulation in Malaysia. Therefore, these changes forced PR practitioner to change and respond to the following nature by improved skills, increased specialization and more understanding the concept of PR. Previous studies in this field emphasize aspects of the role and responsibilities of public relations, the use of social media, communication challenges and crisis management within the organization. Hence, the main focus of this study to identify professional communication from public relations perspectives. This study will examine communication as one of important area in conveying useful information in the health field, especially as the world is facing a pandemic disease Coronavirus 2019 (Covid-19). Selected PR officers from the Ministry of Health (MOH) will be an interview based on the designated criteria. Meanwhile, for content analysis method will be based on the content of a speech by the Prime Minister regarding the standard new procedure (SOP) outlined by $\mathrm{MOH}$. The findings will discover that the new standard of professional communication practice among health care in $\mathrm{MOH}$.
\end{abstract}

2357-1330 @ 2021 Published by European Publisher.

Keywords: Covid-19, MOH, professional communication, public relations, pandemic disease, PR practitioner 


\section{Introduction}

A pandemic is the worldwide spread of a new disease (World Health Organization, 2020). The impact of this pandemic will affect a larger population as people has to lack pre-existing immunity to the Covid-19 virus. As for vaccine still not yet been found, if the proportion of those infected that go on to develop the severe disease is small, the total number of severe cases can be relatively high. Thus, Malaysia also faced with pandemic disease, for example, Influenza and even H1N1 disease once attacked world contagion. Other than that, Malaysia has been startled with Nipah Virus disease in 1998 in the state of Perak, Selangor and Negeri Sembilan. Although the virus is the endemic disease, it affected the health system in Malaysia.

In the past of centuries, there have been pandemics (1918, 1957 and 1968), one of the which - the infamous "Spanish flu" of 1918 - was responsible for 450,000 deaths in US and 50-100 million worldwide (Kotalik, 2006, p.70). Nowadays, the world faced with the pandemic issue, including Malaysia, that is Coronavirus 2019 (Covid-19). A novel coronavirus (Covid-19) is a new corona virus strain that has been previously found in the people (Australia Government Health of Department, 2020). Covid-19 looks set to be the worst infectious disease pandemic of a generation in terms of number infected, mortalities and the unprecedented demand for healthcare services (Currie et al., 2020). According to Gao and $\mathrm{Yu}$ (2020), its rapid spread has not only affected the lives of hundreds of millions of families, but it also disrupted the pace of economic and social development, resulting in incalculable economic and social losses. Many countries take precautions and reconsider by the filter and implement entry restriction foreigner to coming into the respective countries especially. At the same time, the World Health Organization was declared Covid-19 as a pandemic disease due to apparent case increase throughout the world.

\section{Problem Statement}

The pandemic issue happened in contagion world give lots of effect to many countries. The front liner needs to work hard and jeopardized their life and family to help the government to handle the crisis. Many countries implemented lockdown to control this situation, like in China.

Following the Covid-19, our Prime Minister Tan Sri Muhyiddin Yassin was announced the movement control order (MCO) on March 16, 2020. The implementation of MCO to prohibit mass gathering, ban Malaysian to leaving this country, entry restriction to foreigner into Malaysia, and all the universities, schools, kindergartens and non-critical sector closed for 14 days starting on 18 March 2020. The main reason for MCO to break the Covid-19 chain as the virus used the human body as a host to spread. The MCO order is to restrict Malaysian to gather, having contact with each other's, and retain social disclosing with 1 meter away.

Meanwhile, in the Ministry of Health, led by Director General of Health, Tan Sri Dr Noor Hisham Abdullah, responsible for handling the patients of Covid-19 in Malaysia. During MCO, the press conference was held every day to give an update to Malaysian regarding this issue. 
Subsequently, the number of cases increased every day, due many Malaysian is disobedient to MCO order. As of 10 of November 2020, table 1 shows the number of specific instances in Malaysia with a total of 42,050 confirmed cases reported. A total of 30,304 cases of Covid-19 patients has made a full recovery and discharged from the hospital and 300 deaths cases.

Table 1. Total cases in Malaysia (Ministry of Health, 2020) updated 10 November 2020

\begin{tabular}{cc}
\hline Total of cases & No of cases \\
Recovery & 42,050 \\
ICU & 30,304 \\
Deaths & 82 \\
\hline
\end{tabular}

Initially, this outbreak is succeeding controlled by the Malaysia government. However, the second cluster happened when the 26th case had contacted with publics and caused this outbreak to spread rapidly. Moreover, after the tabligh assembly at the mosque in Petaling Jaya, a hundred cases were reported around Malaysia. Furthermore, the Sabah election took place on 26 of September, 2020 caused increasing pandemic in contagion Malaysia especially in Sabah. Later, MOH identified many clusters contribute to Covid-19 cases in Malaysia. Based on MOH statistic, a total of 130 Covid-19 clusters in Malaysia end. However, a new cluster emerged and caused Covid-19 to re-spread in Malaysia. According to the Ministry of Health (2020), the Malaysian government has intensified the activities of detection, screening, testing, isolation and treatment by using targeted approach. These activities were carried out in collaboration with many government agencies and non-governmental organizations.

PR practitioner in MOH plays a significant role in delivering information related to the covid-19 outbreak. They are also responsible for advising the government on the implementation of the MCO based on a daily basis case. In fact, they also provide information to the public and give awareness and advice on the pandemic disease. A PR practitioner handled the data at $\mathrm{MOH}$. They used various medium in transmission of information. For example, social media (Facebook, Twitter, Instagram, etc.), instant messaging (WhatsApp and Telegram), website, press conference and traditional media. According to Zeti (2019), social media have made timely and interactive communication possible thus often perceived as ideal tools to manage organizations and stakeholders' relationship; the essence of public relations function.

Functions of PR become extensively. There are two core elements; however: communication and management (Dibb et al., 1996). PR need to manage communication to the public, and at the same time, they need to have strategic planned and facilitated the communication with its people. Based on this, this study will look on possible paths of influences that PR practitioner will encounter during handling crises and their judgement in evaluation practices. The developments and changes have made the world smaller: changes such as globalization, communication technology, information technology, and other phenomena guarantee that people will be influenced almost everywhere by events anywhere in this world. These 
developments have created great opportunities and several challenges for public relations practitioners (Idid et al., 2016a; Idid et al., 2016b).

This means that PR practitioners play essential roles in conveying the compelling message to the public. Before this, professionalism does not consider PR as an area that needs much expertise. They would rather major in other disciplines such as business, accountancy or science and still finds themselves in a PR job. Most of those who entitled to the positions of PR in both government and private organization is not a PR major. Some of them claim to be practitioners because they are practising journalists.

The organization are simply hiring by PR practitioners because they are good at writing and have an English educational background. PR practitioners not just need them good in hand, but they also should mastery in other skills. Top-rated competencies sought at the organization level for PR practitioners are; writing skills, critical thinking, problem-solving skills, right attitude, the ability to communicate publicly and initiative (Maina \& HellenMberia, 2014, p. 342; Tikolo, 2011). Most PR practitioners and management are not well understood about the concept of the PR profession, though they engaged in it on daily activities.

PR practitioners in $\mathrm{MOH}$ not only responsible for activities of the organization, but they are also a front liner during the crisis. Other than that, the PR practitioner view as one decision-maker in the management. It is because, they need to decide to delivering the appropriate information without trigger any panic to the public. However, many organizations seem not to appreciate the roles of PR and hence do not consider PR as an integral part of the professional profession in the organizations. PR functions become more complicated, especially dealing with an international health issue like Covid-19. This outbreak not only perceive a bad reputation to the public but it also can affect the relationship between the organization and its public.

\section{Research Questions}

This study aims to provide insight understanding of PR practitioners from professional communication perspectives. It looks on PR practitioners have to change, and improved skills based on the current issue happened in the organization by answering the following research questions below:

- How MOH creating the message to the public?

- What is a major outbreak disease communication challenge (s)?

- What are the ethical challenges (if any) confront in outbreak disease?

\section{Purpose of the Study}

This study will look at how PR practitioners take initiatives by improving communication skills and technique as professional communication following the outbreak. PR practitioners need to provide accurate and appropriate information to its public. The PR practitioners also responsible to create awareness among its public and helps the government to control the disease by provide better and safe service to its customers. These are following research objective to answer the research questions above: 
- To identify MOH creating the message to the public.

- To analyse major outbreak disease communication challenge (s).

- To analyse the ethical challenges, happen during outbreak disease.

\section{Research Methods}

This conceptual paper will be conduct by using qualitative method which is in-depth interview. There are 5 sections under Corporate Communication Unit in $\mathrm{MOH}$, which Administration Corporate Affairs, Strategic Communication, Mass Media and Complaint Management. Thirteen of PR practitioners in Corporate Communication Unit involved, located in $\mathrm{MOH}$ Putrajaya to reach an objective of exploring professional communication field. This study will conduct using qualitative method in order to gain probe perspectives of PR practices from MOH. This method can identify the meaning and experienced gain by the PR practitioner while handling information about pandemic disease. By using this method will expose the standard of procedure (SOP) and messages outlined by $\mathrm{MOH}$.

\section{Findings}

The expected findings of the study will answer our research questions and mostly it will provide a thorough perspectives of PR practitioners who handles information about pandemic disease in the country.

\section{Conclusion}

Above all, this study will explore how PR practitioner in $\mathrm{MOH}$ evolve and perceived its reputation while handling the international health issue like Covid-19 in terms of professional communication. PR represents the organization whereas the functions not only to provide effective communication to the public but they also responsible as the decision-maker and one of the member crisis management team. $\mathrm{MOH}$ involving with multiple government sector and non-governmental sector. According to Gao and $\mathrm{Yu}$ (2020), governments are no longer the sole providers of public services, but should instead set rules and establish and order for the interaction of multiple stakeholder for collective action.

Other than that, this research also to identify influential medium used by $\mathrm{MOH}$ in communicating information to the public during disease outbreak, for example social media (Facebook, Twitter, Instagram and etc.), instant messaging (WhatsApp and Telegram), website, press conference and traditional media. Moreover, it also examines the challenges communication happen during communication the information to public. Thus, possibility to PR practitioner in $\mathrm{MOH}$ faced with ethical challenges in delivering information the public by protecting information of patient under investigation (PUI), patient under surveillance (PUS) and protecting confidential information related to this pandemic issue. 


\section{Acknowledgments}

We would like to express sincere thanks to Assoc. Dr. Nurhafezah Yusof and Dr. Romlah Romli, as well our colleagues for providing us this opportunity and help us to produce this article. We also want to thankful to our families who give us full support and affection during our discussion to our subject.

\section{References}

Australia Government Health of Department (2020). Informations of close contact of a confirm case. UpToDate. May 26, 2020. https://www.health.gov.au/sites/default/files/documents/2020/01/novelcoronavirus-information-sheet-for-people-who-have-had-close-contact-with-a-confirmedcase_1.pdf

Currie, C. S. M., Fowler, J. W., Kotiadis, K., Monks, T., Onggo, B. S., Robertson, D. A., \& Tako, A. A. (2020). How simulation modelling can help reduce the impact of COVID-19. Journal of Simulation, 14(2), 83-97. https://doi.org/10.1080/17477778.2020.1751570

Dibb, S., Simkin, L., \& Vancini, A. (1996). Competition, strategy, technology and people: The challenges facing PR. International Journal of Advertising, 15(2), 116-127. https://doi.org/10.1080/02650487.1996.11104641

Gao, X., \& Yu, J. (2020). Public governance mechanism in the prevention and control of the Covid-19: Information, decision-making and execution. Journal of Chinese Governance, 5(2). https://doi.org/10.1080/23812346.2020.1744922

Idid, S. A., \& Arandas, M. F. (2016a). Professionals values, ethics, and professionalism of public relations practitioners. Malaysian Journal of Communication, 32(1), 351-370.

Idid, S. A., Arandas, M. F., \& Kee, C. P. (2016b). Recruiting the public relations officer during British colonial Malaysia. [IUKL International Postgraduate Colloquia], 578 - 587.

Kotalik, J. (2006). Can mandatory vaccination of health care professionals during and influenza pandemic ever be justified? Advances in Bioethics, 9, 69-89. Elsevier Ltd.

Maina, N., \& HellenMberia. (2014). Application of public relations theories in the practice of public relations in national government ministries. International Journal of Education, 2(4), 341-354.

Ministry of Health. (2020). (2020, April 26). Situasi semasa jangkitan penyakit Coronavirus 2019 (COVID-19) di Malaysia. [Press release]. https://kpkesihatan.com/2020/04/26/kenyataan-akhbarkpk-26-april-2020-situasi-semasa-jangkitan-penyakit-coronavirus-2019-covid-19-di-malaysia/

Tikolo, K. L. (2011). The practice of public relations in Kenya: Future growth prospects. Public Relations Society of Kenya Draft Report.

World Health Organization (2020, March 12). WHO announces Covid-19 outbreak a pandemic. http://www.euro.who.int/en/health-topics/health-emergencies/coronavirus-covid19/news/news/2020/3/who-announces-covid-19-outbreak-a-pandemic

Zeti, A. A. (2019). Embracing social media: The change and disruption to public relations practices in Malaysia. Malaysia Journal of Communication, 35(1), 319-337. 